\title{
Multiculturalism and Settlement: The Case of Dutch Postcolonial Migrant Organisations
}

\author{
Ulbe Bosma • Marga Alferink
}

Published online: 29 July 2011

(C) The Author(s) 2011. This article is published with open access at Springerlink.com

\begin{abstract}
This article examines the effects of multiculturalism of the 1980s and 1990s on the organisational patterns of immigrant populations in the Netherlands. This is a controversial topic in this country since politics of multiculturalism have allegedly excessively sponsored migrant organisations causing their 'fragmentation' and having adverse consequences for these organisations' role in the integration process. Based upon a systematic survey of the available data about postcolonial migrant organisations from 1945 to 2008, our conclusion is that the growth in postcolonial migrant organisations from the 1980 s onwards has been impressive. For this specific category of immigrants, there is, however, little in the way of evidence that links this growth, or fragmentation of the landscape of migrant organisations for that matter, to Dutch multicultural minorities policies. Much of the growth should be related to the global phenomena of emerging identity discourses and increasing levels of identity politics. The policy implication is that, at least for the Netherlands, government policies creating favourable conditions for migrant organisations have been discarded without proper justification as counterproductive.
\end{abstract}

Keywords Multiculturalism · Migrant organisations · Opportunity structures $\cdot$ Social capital $\cdot$ Postcolonialism

In 1979, the Dutch government acknowledged that racial and ethnic diversity would be a permanent feature of the Netherlands. To address this multi-ethnic future, a 'minorities policy' was formulated that was moderately multicultural in nature (Wetenschappelijke Raad voor het Regeringsbeleid (WRR) 1979, xviii; Ministerie van Binnenlandse Zaken 1981). One of the key objectives of the policy was to encourage immigrants from non-western backgrounds to organise themselves. This was a response to the perceived dangers of political and social exclusion. However, the role of migrant organisations came under increasing criticism during the 1990s, when 
government policies shifted their focus to improving education, and thereby job opportunities, for individual migrants. Particularly since 2001, migrant organisations have taken part of the blame for what has become known in the Netherlands as the 'multicultural drama' (Scheffer 2000). Since Scheffer's publication, the Dutch discourse on multiculturalism took a turn to a 'new realism' (Prins 2002).

Doubts about the positive role of migrant organisations in the emancipation of newcomers are based upon the assumption that Dutch multicultural policies have fostered organisational fragmentation, leading to a proliferation of small politically powerless associations, fostering segregation rather than social and political incorporation. This view was most notably expressed by Koopmans (Koopmans 2002). ${ }^{1}$ In comparing the effects of policies for social integration in a number of European countries, Statham and Koopmans comment on Dutch integration policies that: 'Too much state sponsorship for multiculturalism appeared to have led to the fragmentation of migrant communities along ever smaller ethnic and religious group lines, resulting in an institutionalization of inequality' (Koopmans et al. 2005, 245). ${ }^{2}$ This perspective is clearly contradicted by a number of research projects and publications of the Institute of Ethnic and Migration Studies (IMES) at the University of Amsterdam, which stress the importance of ethnic associations and their capacity to sustain civil society (Fennema 2004; Penninx and Van Heelsum 2004; Penninx and Schrover 2001). Vermeulen's findings on Surinamese and Turkish immigrant organisations in Amsterdam and Berlin underscore that 'fragmentation' can easily be compensated by a high degree of connectivity between organisations (Vermeulen 2006, 160-161). A North-American variant of this IMES position might be Bloemraad's structured mobilisation approach, 'which views political incorporation as a social process of mobilisation by friends, family, community organisations and local leaders that is embedded in an institutional context shaped by government policies of diversity and newcomer settlement' (Bloemraad 2006a: 667).

The complexity of the relationship between government policies and numbers of immigrant organisations also appears from Vermeulen's findings on the Surinamese and Turkish organisations in the Netherlands (Vermeulen 2006, 159-160). These findings suggest that the degree of (pre-migration) ethnic and religious diversity within migrant groups is a particularly important determinant in the initial phase of settlement that heavily interacts with opportunity structures. This is apparently in line with the organisation ecology model of Hannan and Freeman which submits that during the first phase of the organising process an increase in new organisations enlarges their legitimacy and makes it easier for others to start a new organisation. Once the density of the population of organisations has risen to its carrying capacity in terms of available resources (government sponsorship, potential membership, etc.) the number of newly established organisations declines. Elaborating and also slightly reworking this theory, Minkoff argues that a higher organisational density improves the individual organisation's chance of survival, making them less vulnerable to institutional changes but also acts as a basis for new organisational initiatives

\footnotetext{
${ }^{1}$ Koopman's argument was criticised for not presenting the full picture by Böcker and Thränhardt (2003).

${ }^{2}$ Their view is criticised by Engelen and Kastoryano who both claim that by focusing their research on discussions in national newspaper, Koopmans et al. fail to notice the agency of migrant organisations, who are mainly politically active at a local level (Engelen 2008, 131; Kastoryano 2008, 135).
} 
(Minkoff 1995, 122-124). This way the organisational ecology model can explain both the organisations tendency to grow in numbers as well as their increasing connectivity (Vermeulen 2006, 162-163).

No doubt, the theory of organisational ecology provides us with important insights into the complex dynamics of migrant organisations. But it has its limitations, one of which is that it does not take on board the historical dimension. The point to be made here is that the curve in organisational density postulated by the theory of organisational ecology at least covers 30 years, in which both on the side of receiving society and its opportunity structures as well as on the side of the immigrants a lot might change. An often underrated factor is the historical context in which migrant organisations develop their identity politics. Following Calhoun we define identity politics as the aim for public recognition of ethnic, cultural and religious differences and the fulfilment of specific and culturally defined needs (Calhoun 1994, 20-26). Identity discourses and identity politics that emerged together with the concept of multiculturalism in the 1980s, for example, belong to a specific moment in history that was a.o. fostered by an increasing level of global interaction. This may have influenced identity politics of the migrant organisations even stronger than national integration policies, and this may hold true for the Netherlands in particular.

The relationship between postcolonial immigration and the introduction of multiculturalism in the Dutch integration politics provides a case in point to test the assumption that multicultural policies have led to a proliferation of migrant organisations (Bosma 2009, 241). The data collection and research on which this article is based were part of a broader research programme into the history of postcolonial immigration and the status of the Netherlands as a postcolonial society. ${ }^{3}$ Confronted by mounting ethnic tensions and even violence attending the arrival and settlement of groups of postcolonial immigrants in the late 1970s, the Dutch government adopted a policy that was to a certain extent inspired by Canadian multiculturalism (Campfens 1979). In spite of that, and in contrast to Great Britain, Australia and Canada, the uneasy but nonetheless crucial relationship between multiculturalism and postcolonialism has hardly attracted public or even academic attention (Gunew 1997). This lack of recognition of the postcolonial condition of the Netherlands may explain the rather uncritical use of the word 'fragmentation' by Statham and Koopmans to label complex processes of identity politics and their interaction with government policies.

This article is based upon data provided by a systematic survey of migrant organisations established by newcomers who came from the former Dutch colonies; they represent about $40 \%$ of all post-War immigrants from outside Europe. Although these data concern only one particular segment of the Dutch immigrant population, they provide sufficient basis for our purpose of testing the assumption that Dutch government policies have led to a fragmentation of migrant organisations. This assumption was after all not qualified for particular categories of immigrants. The data cover 60 years, stretching from the first repatriates from Indonesia in the 1940s to the Antilleans who arrived in large numbers in the 1990s. Before we present our

\footnotetext{
$\overline{{ }^{3} \text { See, http://www.narcis.info/research/RecordID/OND1316889/Language/nl }}$
} 
research results, we will first briefly describe the groups concerned and our research methods.

\section{The Groups Involved: Indische, Moluccan, Surinamese, and Antillean/Aruban}

In the Netherlands, $6.3 \%$ of the population comes from the former colonies or has at least one parent born there. These people migrated in roughly three different waves. Between 1945 and 1956, almost 90\% of the Dutch citizens who lived in Indonesia, about 300,000 individuals, migrated to the Netherlands. More than $60 \%$ of them were born in the former colony and were often of partly Indonesian descent. In this paper we use 'Indische Netherlanders' for Dutch citizens born in Indonesia and 'repatriates' for metropolitan Dutch people who came back from Indonesia after 1945. In addition to the Dutch citizens migrating from Indonesia in 1951, 4,000 Moluccan colonial soldiers arrived in the Netherlands after they had refused to be demobilised on Indonesian territory. Together with their 8,000 wives and children, they were ordered to embark for the Netherlands and discharged just before debarkation in Rotterdam (Smeets and Steijlen 2006, 67, 79). They were loyal to the Moluccan Republic (Republik Maluku Selatan) that was created in 1950 and subsequently crushed by the Indonesian state, although a small guerrilla movement managed to survive until 1966. In the 1970s, about 180,000 immigrants came from Suriname and from the 1980s onwards another 90,000 arrived from the Antilles and Aruba (Fig. 1).

According to Alba and Nee $(2003,216)$ there are four main indicators of integration: acculturation and language, assimilation, socio-economic attainment, spatial patterns and social relations (measured by intermarriage). As far as language is concerned, the processes of settlement for the postcolonial immigrants were preceded by extensive colonial migration circuits. In the nineteenth century, travelling was confined to the mostly well-educated elites. In the twentieth century, these colonial migration circuits expanded rapidly, particularly among the more educated people. The first groups of post-war immigrants were also relatively well educated. Fifteen per cent of the first waves of Dutch people returning from

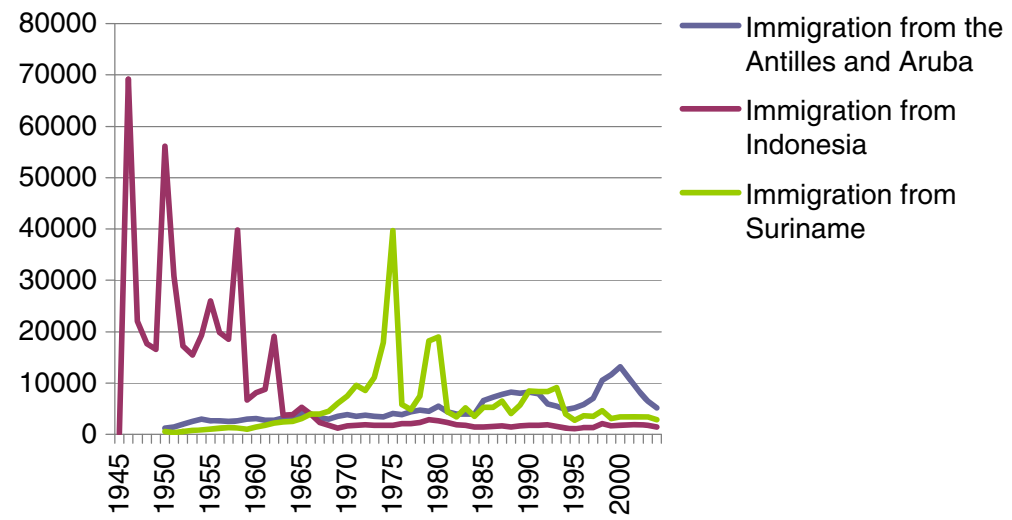

Fig. 1 Adapted from, Netherlands Central Bureau of Statistics 
Indonesia between 1945 and 1949 had an academic education (Kraak et al. 1958, 226). Likewise, until the early 1960 s about $10 \%$ of the Surinamese residents in the Netherlands had an academic education or higher vocational training and until the early 1980 s $16 \%$ of the Antillean immigrants were also well educated (Van Niekerk 2002, 23). The level of education in immigrants declined as the influxes of the respective immigrant groups became much larger, which, of course, was a source of concern for the Dutch authorities. In the 1950s, the Dutch government was reluctant to admit Indische Netherlanders, particularly if they had never lived in the Netherlands. Likewise, in the early 1970s the Dutch government tried to stop the increasing numbers of Surinamese immigrants by expediting the independence of Suriname. In both cases, the attempts to stem the migration influxes had little effect.

As far as work (social-economic attainment) is considered, conditions changed fundamentally over time. A crucial aspect of this was the changing role of the state in the economic sphere. Whereas the government intervened in the labour market on behalf of the repatriates from the newly independent Indonesia in the 1940s, in the 1980s and 1990s the integration of immigrants into the labour market was left to market forces, the employers and labour unions (Van Amersfoort and van Niekerk 2006). The impact of this withdrawal was enormous, especially as in the 1980s the Netherlands was suffering from a severe economic crisis and deindustrialisation. In other spheres of housing (spatial patterns) a drastic change also took place. The central co-ordination of housing and welfare provision that had been in place when the Indonesian repatriates had arrived was disintegrating by the 1970 s, precisely when the Surinamese were migrating in large numbers. The Indische Netherlanders are rather dispersed over the country, whereas Surinamese and Antillean migrants were concentrated in the large cities. Moluccans had been housed in separate districts in about 60 villages.

Taking intermarriage as a parameter of integration, it appears that the affinity of postcolonial migrants for Dutch society is converging over time, and is stronger than that felt by labour migrants. Generally, intermarriage into the autochthonous Dutch population occurs much more frequently among postcolonial migrants than among labour migrants from Morocco and Turkey who started to settle in the Netherlands from the late 1970s onwards (Sociaal Cultureel Planbureau (SCP) 2007, 39). In the $1950 \mathrm{~s}$, more than half of the Indische Netherlanders married outside their own group (Willems 2001, 201). This figure was slightly lower for the Moluccans. According to figures from the 1960s only about one third of them married into autochthonous Dutch society. This difference can be easily explained by their isolated housing in barracks - and later on in separate residential areas in Dutch villages and townsand the long upheld ideal of a return to the Moluccas. At present about one third of the Surinamese and 50\% of the Antilleans are married to autochthonous Dutch people. For the second generation, the percentages are considerably higher than for the first (Table 1).

The postcolonial immigrants had different levels of education and different degrees of affinity for Dutch culture, and almost all of them were legally Dutch citizens, with the exception of the Moluccans. Many Moluccans had refused to apply for Dutch citizenship during their exile in the Netherlands and about $80 \%$ did not have a Dutch passport in the 1970s (Jones 2007, 129). The Surinamese, the Afro- 
Table 1 Postcolonial immigrants in the Netherlands, 1st and 2nd generations (2006)

\begin{tabular}{lcrr}
\hline & First generation & Second generation & Total \\
\hline Indische Netherlanders and Dutch repatriates & 204,000 & 315,000 & 519,000 \\
Moluccan & 26,000 & 32,349 & 58,349 \\
Surinamese & 187,483 & 144,417 & 331,900 \\
Antillean and Aruban & 80,102 & 49,581 & 129,683 \\
Total & 497,585 & 540,868 & $1,038,932$ \\
\hline
\end{tabular}

For Suriname and the Antilles (including Aruba), see Netherlands Central Bureau of Statistics. For Indische Dutch and Moluccans, see Beets et al. (2002)

Surinamese in particular, and the Indische Netherlanders were the most proficient in Dutch, whereas the Antilleans had the least affinity for Dutch language and culture.

The postcolonial migrants have long-term relationships with the Dutch state, and also with Dutch society, however strained and painful these may be. The immigrants from Indonesia could count on the solidarity of their relatives in the Netherlands, the Dutch society at large, and were able to help each other. For example, former key figures of the Dutch empire had not forgotten that the 'Ambonese' - the name the Moluccans were given in the colonial army-had served the Dutch in Indonesia for three centuries. The political relationship with the metropolitan state was quite different for the postcolonial immigrants from the West who were the descendants of slaves and indentured labourers. As a consequence, over the past 60 years the political orientations of the postcolonial migrant organisations in the Netherlands have run the full gamut from colonial revanchism to communism and Black Power. However, all the organisations held grievances against the Dutch government and society.

The Second World War and the subsequent decolonisation process were deeply traumatic experiences for many postcolonial migrants from Indonesia. Moreover they, and this pertains to the colonial civil servants in particular, had substantial financial claims. In the early 1950s, they pressured the Dutch government into rescuing their pensions, the responsibility for which had been transferred to an unwilling Republic of Indonesia. Another issue was that during the Japanese occupation of Indonesia the majority of the Dutch men (as well as the women and children) had been interned and during these years their salary payments had been discontinued. The backpay of these salaries has never taken place, which is still a bone of contention between the Dutch government and the, now elderly, former Dutch civil servants of colonial Indonesia.

\section{Mapping Migrant Organisations}

To determine how postcolonial immigrant groups articulated themselves through organisations, we can rely on methods developed by Jean Tillie and Meindert Fennema at the IMES in Amsterdam (Fennema and Tillie 1997). Various research projects at this institute have focused on Dutch immigrant organisations. In the Netherlands most of these organisations can be found in the registers of the national 
Chambers of Commerce. The great majority of migrant organisations took a formal status in order to start a bank account and rent a location for their activities. In addition to using the registers of the Chambers of Commerce, we have also made an extensive search using the Internet and the abundantly available secondary literatureparticularly to trace older organisations that have already disappeared - as well as primary sources. A selection of the secondary literature searched is listed on the website that presents the database, and which can be consulted at www.iisg.nl/research/ migrantenorganisaties.php. ${ }^{4}$ An extensive bibliography is included in the Dutch language book by Bosma (Bosma 2009, 403-434)

We have found almost 2,600 organisations that can be attributed to the various postcolonial immigrant groups. About $80 \%$ of these organisations were registered with the Chambers of Commerce; the remaining $20 \%$ are mostly churches, informal organisations, website groups and so on. We did not apply a particular definition of an 'organisation' to our search, although in practice we looked for groups that enter the public sphere and proclaim themselves to be an organisation with stated objectives.

In spite of the fact that we cannot catch all the fish in the pond, we think that our database of postcolonial migrant organisations allows us to compare between immigrant groups and provides the necessary data to analyse the interactions between government policies and the developing landscape of immigrant organisations. The database also enables us to describe the evolution of the organisational landscape of the postcolonial immigrants over time. We have the dates of establishment for about $92 \%$ of the 2,600 organisations and we know whether the organisations still exist. We do not have consistent information, however, on the exact dates of dissolution for those organisations that have disappeared. ${ }^{5}$ This is a disadvantage in terms of establishing the development of organisational density of migrant organisations over time. This partly explains why we have based our analysis on the growth or decline of the numbers of newly established organisations rather than on the number of organisations at any given moment. In addition, we have categorised these organisations both according to group-specific markers as well as through objectives. Group-specific markers are country of origin, ethnicity, religion, 'youth', 'elderly' and 'women' while objectives cover areas of interest such as 'welfare', 'heritage', 'religious facilities', 'sport' and so on. This categorisation was done through our own research and was double-checked with representatives of migrant organisations.

We have not made a distinction between organisations that were established by immigrants themselves and those established by other agencies working on their behalf. In fact, government sponsored agencies such as the community development and welfare foundations, played an important role in the 1970s as voices for the Surinamese and Antillean newcomers and the Moluccans (WRR 1979, 173). Another deviation from what is customary in this type of research, and from similar projects at IMES in particular, is that our research does not apply network analysis to

\footnotetext{
${ }^{4}$ A full reference list is offered by the bibliography of Bosma, Terug uit de koloniën.

${ }^{5}$ For $99.5 \%$ of the 2,068 organisations that are registered with the Chambers, we have the dates of foundation. Of the 452 (13 June 2008) organisations that are not registered we have 244 dates of establishment. So far, we have discovered that $1 \%$ of the organisations traced in the registers of the Chambers of Commerce existed for years before they were registered.
} 
establish the level of collaboration (connectivity) between migrant organisations (Tillie and Fennema 1997; Fennema 2004). In our research, we did, however, place the organisations on a scale illustrating their position in terms of national, regional and local significance, and made the assumption that the national organisations include certain levels of bonding between migrant organisations. Moreover, changing opportunity structures and differences in social capital have had a distinct impact upon the scale of operations, as we will show. To a certain extent, the scale and number of organisations are inversely correlated.

The patterns of migrant organisations follow their own rhythm as Van Heelsum has demonstrated at the basis of her research into a great many migrant organisations in the Netherlands (Van Heelsum 2004). The number of new organisations is a peak in the early years of settlement for any migrant group (Hannan and Freeman 1989, 243). This already partly explains the rise of Surinamese organisations in the 1970 s and the rising number of Antillean organisations by the end of the 1990s. Fifteen to 20 years after the settlement process the goal of finding housing and work and establishing religious facilities, journals etc., is more or less complete. After one generation, the number of new migrant organisations tends to decline. In the case of the Surinamese organisations this seems to have happened, but despite this pattern there was no such decline in the associational life of migrants from Indonesia in the 1980s. We will return to this later on. For Antillean organisations it is still too soon to tell whether the number of newly founded organisations will decline. Thus, the basic pattern in the evolution of the organisational landscape is shown in the graph below (Fig. 2).

What we see here is a decline in the number of newly founded Surinamese organisations in the mid-1980s, exactly at the time that the multicultural policies of the Dutch government took effect. However, the number of Surinamese organisations had been rising since 1973, when the large-scale influx of Surinamese immigrants commenced. From the early 1970s onwards, subsidies for migrant organisations were made available at the municipal level. Most of the Surinamese immigrants arrived between 1975 and 1979. At that time, the number of Surinamese residents in the Netherlands was growing so rapidly that it led to a diminishing Surinamese organisational density (i.e. a decreasing number of organisations per capita) in Amsterdam, as Vermeulen has shown (Vermeulen 2006, 138).

The number of newly founded Surinamese organisations declined sharply in the mid-1980s. Since Surinamese organisational life had become singularly reliant upon

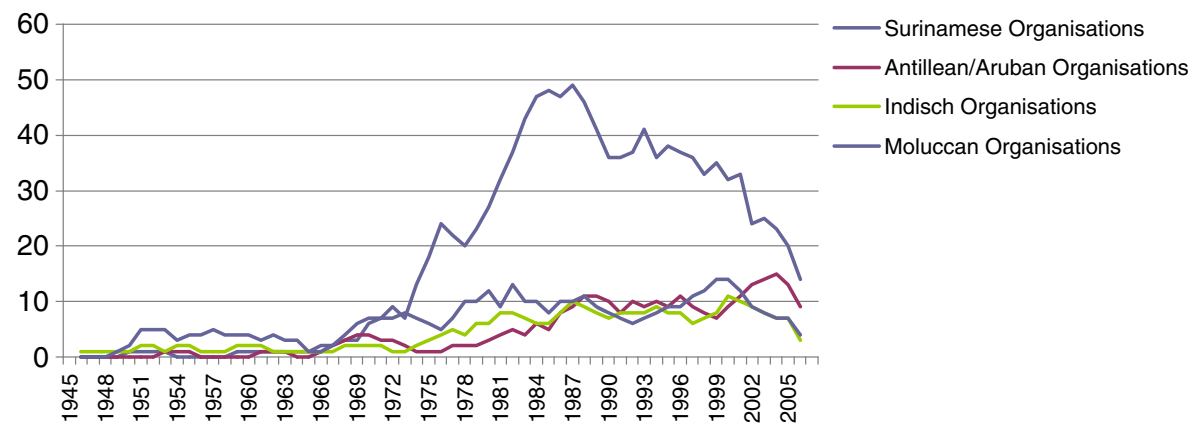

Fig. 2 Newly established migrant organisations per year. Moving three yearly average 
government sponsorship in the 1970s, we agree with Vermeulen that its declining numbers in the 1980s was in all likelihood caused by shrinking subsidies (Vermeulen $2006,132,140)$. At the same time, many new organisations were being established by Indische Netherlanders without government sponsorship. As we will demonstrate, the declining numbers of newly established Surinamese organisations were related to changing opportunity structures, whereas the rise of the migrant organisations of first- and second-generation migrants from Indonesia in the 1980s and 1990s had little to do with multicultural government policies. Identity, trauma, heritage and transnationalism became keywords which characterised many of the new postcolonial migrant organisations of the 1980s and 1990s, and the far majority of the immigrant associations that played a role in these areas operated outside government sponsorship.

The number of Surinamese organisations in the graph is three or four times as large as that of the other migrant groups. However, if we relate the number of organisations to the size of the respective migrant populations, the picture is slightly different. It then becomes clear that from the early 1950s onwards the Moluccans were the most active in this field. The Moluccan self-representation as exiles and their spatial isolation in the Netherlands had created the perfect breeding ground for factionalism and strife. This was not unusual for smaller refugee immigrant populations in the Netherlands, as Van Heelsum has demonstrated (Van Heelsum 2004, vol. 1, 62). In addition, the colonial army had recruited young Moluccan men from many different islands and villages. Once in the Netherlands they were housed in 60 different locations and clearly they presented a special case. The organisational density of the Surinamese - and the Antilleans to lesser degree - was not out of tune with that of the Moroccans and Turks, respectively 1:409 and 1:303 (Ibidem). In the landscape of Dutch migrant organisations, the four large immigrant groups from outside Western Europe (the Moroccans, Surinamese, Antilleans and Turks) share approximately the same organisational density (Table 2).

The discrepancy in the organisational density of the two largest postcolonial groups, the Indische Netherlanders and the Surinamese, is striking. Obviously, the figures in the table above represent the organisational density in 2006 and are not entirely comparable. But the organisational densities of Indische and Surinamese organisations 3 years after their first and largest immigration influx differ even more strikingly: the density of Surinamese organisations in 1978 was 1:837 and the

Table 2 Organisations per capita, corrected for 34\% dissolved organisations, but not including Antillean/ Surinamese organisations

\begin{tabular}{lccc}
\hline Group & $\begin{array}{l}\text { All postcolonial } \\
\text { organisations 1945-2007 }\end{array}$ & $\begin{array}{l}\text { First and second } \\
\text { generation (2006) }\end{array}$ & $\begin{array}{l}\text { Fraction (over 66\% of the } \\
\text { organisations in column 2) }\end{array}$ \\
\hline Surinamese & 1,223 & 331,900 & $1: 411$ \\
Indische Netherlanders & 338 & 519,000 & $1: 2,319$ \\
Moluccan & 454 & 58,349 & $1: 195$ \\
Antilles/Aruba & 346 & 129,683 & $1: 568$
\end{tabular}

Adapted from, www.iisg.nl/research/migrantenorganisaties.php 
organisational density of Indische organisations in 1952 was 1:7,304. ${ }^{6}$ This difference can be explained by a number of factors. Firstly, the ethnic and religious diversity within the Surinamese immigrant population was considerable. Secondly, Hindustani groups, which were part of the Surinamese migration, had to establish their own religious facilities. ${ }^{7}$ Thirdly, opportunity structures had changed drastically in the 25 years between the arrival of the repatriates from Indonesia around 1950 and the immigration from Suriname around 1975. Finally, newcomers' social capital in terms of how to establish and maintain organisations differed significantly.

\section{Ethnic and Religious Diversity, Social Capital and Opportunity Structures}

Coming from a plural society, the Surinamese immigrants from various ethnic backgrounds - Afro-Surinamese, Hindustani, Maroon, and Javanese - all established their own organisations. In this respect the identity politics in the Netherlands were a continuation of the pillarised politics of Suriname. To this it should be added that Surinamese independence was pushed through by the Afro-Surinamese government against fierce resistance from the Hindustani opposition. Collaboration between Hindustani and Afro-Surinamese immigrant organisations proved to be extremely difficult in the late 1970s and early 1980s (Bosma 2009). A second factor is that there were no Hindu temples, and hardly any Mosques, when the Hindustani arrived in the Netherlands. Their situation was very different from that of the Antilleans who are mostly Catholic, or the Afro-Surinamese who are members of the Moravian Brotherhood, which was already established in the Netherlands, or the Indische Netherlanders who were either Protestant or Catholic. Almost half (254 out of 547) of the Hindustani organisations are religious in character, widely exceeding the $15 \%$ of the Moluccan and Turkish organisations and 24\% of the Moroccan organisations that are religious in character (Van Heelsum 2004, 64). This high percentage of religious organisations among the Hindustani population is the result of a convoluted colonial migration history. Hindustani contract labourers on Surinamese plantations were recruited from many different villages, and therefore had many different religious and caste backgrounds. This led to a high degree of religious fragmentation and religious pillarisation within the Hindustani population.

The great majority of postcolonial immigrants were Dutch citizens and most of them had received a basic education, although the Indische Netherlanders and repatriates were by far the best educated. Both the Indische Netherlanders and the Afro-Surinamese were highly politically mobilised in colonial times. However, the structure of their organisations was radically different. While the Surinamese organisations were mainly based in and just around Paramaribo, the organisations of the Indische Netherlanders covered large parts of the Indonesian archipelago. Indische and repatriate associations in the Netherlands could build upon their

\footnotetext{
${ }^{6}$ In 1978, the Surinamese population in the Netherlands amounted to 128,100 persons and the number of Surinamese organizations was 153. Assuming that since 1945 300,000 repatriates arrived from Indonesia in the Netherlands, the number of Indische Netherlanders living in the Netherlands in 1952 was approximately 168,000. The number of Indische organizations in 1952 was 23.

7 The term Hindustani refers to contract labourers with various religious backgrounds who had been recruited from India to work on the Surinamese plantations.
} 
organisational experience in setting up branches, collecting membership fees and circulating journals over long distances. Once in the Netherlands, the effects of the differences in social capital were reinforced by a shift in opportunity structures from the national to the municipal level. In order to make a proper comparison we have to look at the first 15 years of settlement. Between 1945 and 1960 the Indische Netherlanders and repatriates established 20 new national and only three local organisations, whereas between 1975 and 1990 the Surinamese established 67 new national and 330 new local organisations (of which 120 were religious institutions and religious federal structures) (International Institute of Social History (IISH) 2008). The two most powerful organisations among these 20 Indische national organisations had 30 to 40 local branches. ${ }^{8}$ During their years of settlement the Surinamese immigrant organisations were far more divided than the Indische in terms of ethnicity, scale and membership figures. In addition, Indische organisations are usually associations with members, whereas among Surinamese migrants foundations are more common. ${ }^{9}$ The latter type of organisation is more dependent upon government subsidies for its survival than associations with fee-paying members.

In the 1950s and 1960s, welfare work for the repatriates from Indonesia was coordinated by a Central Committee (CCKP) — with many local committees all over the country - in which non-governmental organisations of repatriates and the churches worked together (Willems 2001, 102). Integration policies were coordinated at the national level and the Indische organisations operated likewise. In the 1970s, Surinamese organisations did not become involved in policymaking at a national level but in social work at the municipal level and sometimes even in unrewarding and dangerous activities for semi-volunteer organisations, such as providing help for drug addicts.

\section{The Effects of the Minorities Policies or Multicultural Policies of the 1980s}

Though the 'fragmentation and pillarisation' of Surinamese organisations contrasts strikingly with Indische organisational unity, it was not exceptional among migrant groups in the Netherlands (Van Heelsum 2001). Moreover, the Surinamese diversity was rooted in a plural colonial society and developed in the 1970s rather than in the 'multicultural 1980s'. In fact, the minorities policies of the early 1980s tried to restore what could be considered as the derailed immigration and settlement policies of the Dutch government of the 1970s. The community development approach with its strong assimilationist features had worked very well during the Indische repatriation, which went down as a success in Dutch history. The model of the Indische integration still dominated in the $1970 \mathrm{~s}$, but it met with resistance from both Moluccan and Surinamese organisations. Moluccan organisations still held on to the ideal of returning to a free Republic of the Moluccas and considered integration

\footnotetext{
${ }^{8}$ This refers to Pelita and NIBEG.

${ }^{9}$ Between 1945 and 1960, 41\% (7 out of 17) of the Indische organisations were associations, and $35 \%$ (6 out of 17) were foundations. Between 1975 and 1990, 34\% (174 out of 513) of the Surinamese organisations were associations and 63\% (323 out of 513) were foundations.
} 
policies as a threat to this ideal. Impressed by violent train hijackings by radical young Moluccans that deeply shocked Dutch society, a compromise was found. In 1976 the Moluccan Welfare Council was established with eight out of 19 seats allocated to Badan Persatuan, the leading Moluccan political organisation (Smeets and Steijlen 2006, 245). The relationship between the Surinamese organisations and the Dutch Ministry of Welfare was rather frosty. Surinamese organisations held on to the ideal of a return to Suriname, which in the view of the Dutch government was unrealistic (Bosma 2009). While there had been close collaboration between the organisations of the repatriates and the Dutch government over the issue of housing, Surinamese spokesmen condemned the attempts of the government to disperse the Surinamese across the Netherlands as an attack on their newly gained sense of Surinamese nationhood (Suriname had only become independent in 1975). There was mistrust between the Ministry of Welfare, the Surinamese organisations and contemporary local welfare foundations staffed by Surinamese (Bosma 2009).

The minorities policies of the early 1980s tried to break this deadlock by making a distinction between welfare work and political empowerment. The importance of the Dutch government talking directly to migrants themselves rather than to the professional national welfare network was underlined (WRR 1979, 17). Or to put it differently, the minorities policies of the early 1980s, and particularly the desire to speak to the immigrants directly, should be seen against the backdrop of a government struggling against powerful welfare conglomerates, which, according to some contemporary observers, had placed themselves between the government and the population (Van Doorn and Schuyt 1978). Moreover, there was a broad political consensus that national welfare policies should be decentralised, a process that had already been set in motion in the 1970s, but began to take shape seriously from 1983 onwards.

The Dutch minorities' policies were formulated in a sober atmosphere. Among the postcolonial immigrant groups, unemployment among the Moluccan and Surinamese youth increased rapidly, financial deficits in the Dutch government soared, and with little likelihood that the Surinamese and guest workers from the Mediterranean countries would return, there was little room for optimism. This was happening, as Vermeulen has described for Amsterdam, alongside budget cuts and the break-up of unified welfare organisations for specific minorities. More organisations became eligible for funding, but with less money available (Vermeulen 2006, 134-135). The Surinamese welfare foundations were wound up and the saturation of local socio-cultural organisations, as well as another reorientation in minorities policy from 'self-organisation' towards education and employment, ledas far as postcolonial migrant organisations were concerned - to a decline in the number of new Surinamese organisations during the 1980s. The disenchantment among policymakers with migrant organisations was complete in the early 1990s (Penninx and Slijper 1999), the heydays of multiculturalism. Greater emphasis was given to education and the employment of individuals rather than the empowerment projects of groups of people or certain districts (Wetenschappelijke Raad voor het Regeringsbeleid 1989). The debate about minorities was rapidly subsumed into the issue of 'cumulative urban problems', which included issues such as unemployment, drug addiction, crime and school truancy. 


\section{The Trauma of the Second World War in Asia}

The causes of the declining number of newly established organisations and the waning organisational interest of the Surinamese in the 1980s were rooted in the 1970s. This decline was partly the result of decentralisation and partly stemmed from the earlier availability of government subsidies for migrant organisations at the municipal level. This availability of funding often induced the Surinamese groups to opt for the establishment of a foundation instead of an association, which made them less effective in terms of mobilisation. The participation of Indische Netherlanders in ethnic associations was still at the level of about 40\% in the 1980s (Bosma 2009). The 'identity politics' of the Indische organisations related to the Second World War in Indonesia were particularly vocal and the Dutch government became increasingly susceptible to these. The Indische Netherlanders and repatriates, who were excluded from the multicultural policies, struggled to be included in the central chapter of Dutch identity formation: the Second World War. One of their greatest grievances was that their massive internment in Japanese detention camps (about 100,000 Dutch civilians were interned and an additional 42,000 had been prisoners of war) had not received proper recognition in Dutch society. Moreover, neither the soldiers nor the civil servants had received any backpay from the Dutch government for the 3 years they had spent in Japanese internment camps.

Backpay is something the Dutch government has never been willing to consider to date, although in the 1970 s and 1980 s the government became more susceptible to claims that were related to the consequences of the Japanese occupation of Indonesia between 1942 and 1945. Both Indische Netherlanders and repatriates, as well as Moluccans who had endured lasting physical and psychological damage from the war, became eligible for a war victim's allowance. Somewhat belatedly, their rights were brought on a par with those who suffered from persecution during the German occupation of the Netherlands. For the first time in 1970, the anniversary of the capitulation of Japan was commemorated separately on 15 August instead of 5 May, the day the German troops in the Netherlands had surrendered. It was conceived by the Dutch government as the first and the last separate commemoration. But 10 years later, another commemoration was held on 15 August. This time it was organised by a union of 23 Indische organisations and the Moluccan Badan Persatuan. Since 1980 the separate commemoration has become a yearly event. In 1988, the victims of the war in Asia were granted their own monument in The Hague.

As the first generation of immigrants from Indonesia was putting forward its claims regarding the Japanese occupation of Indonesia, it also began to look back on its youth in Indonesia. Meanwhile, the second generation of immigrants from Indonesia became engaged in a search for its Indonesian roots. In 1982 the Moluccan magazine Tjenkeh — edited by young Moluccan intellectuals-reported that there was a lot of 'nostalgia and identity strengthening' happening (Tjenkeh 1982) Within the existing structures - mainly magazines, museums and Pasarsthere was a growing interest in colonial history and in Indonesian culture in general. 'Indische' became increasingly associated with history and identity. At the same time, the Moluccan focus on Indonesia increased. And whether we take the Indische journal Moesson, or the Moluccan Marinjo or Tjenkeh, we see the same tendency to look back on the past. The 1980s were also the beginning of the quest to include the 
experiences of the Moluccans, descendants of slaves and the non-white Dutch from Indonesia into Dutch history writing. The second generation from Indonesia distanced itself from the often colonial mental make-up of most of their parents' organisations. Second-generation Moluccan intellectuals distanced themselves from the ideal of a Free Republic of the Moluccas. It considered this political quest as too compromised by colonial revanchism and too focused upon the special relationship that had existed between the Moluccans and the Dutch in the colonial army. Following this trend, a few years later the oldest Indische journal, Moesson, had to defend itself against criticism by Indische intellectuals that it was indulging itself in politically insensitive colonial nostalgia. Members of the second generation created their own organisation of 'Indische descendants' in order to leave colonialism behind and relate to modern Indonesia.

In 1986, the Indische Scientific Institute was founded, the Moesson Indische bookshop was opened, and funds for the Moluccan Museum were obtained from the Dutch government. Indische and Moluccan groups had acted to preserve their heritage simultaneously but completely independently from each other. The common denominator was the realisation that soon the first generation would no longer be alive. It also became clear that academic work on the histories of the postcolonial immigrants was still in its infancy (Bosma 2009). A long struggle commenced for state-commissioned histories on the immigrants from Indonesia. Prime Minister Ruud Lubbers intervened in 1991 in favour of the writing of an Indische history, which resulted in four volumes on the history of the Indische Netherlanders appearing between 2001 and 2006. In 2006, a history of the Moluccans also appeared, commissioned by the Minister for 'Large Cities and Integration', Rogier van Boxtel. In the late 1990s and early 2000s various attempts were made to establish an 'Indische House' for the commemoration of the War in Asia, without much success as the institution went bankrupt twice.

However, most initiatives in the field of cultural heritage and ethnic festivals were undertaken without government sponsorship or with only minimal subsidies. This is particularly true for the Indische Netherlanders, who did not belong to the official minorities. From the late 1950s onwards, an Indische cultural scene had been developing and by the 1980s it consisted of about 30 cultural markets, the so-called Pasar Malams, with the major event being the Pasar Malam Besar (the big evening market) in The Hague, which attracted between 130,000 and 160,000 visitors. Also completely outside the purview of state-sponsored organisations is the immense library on colonial Indonesia and the flourishing 'nostalgia' literature. This production of literature and the fact that one third of the Indische organisations established since 1991 are dedicated to the past are marked features of Indische postcolonial life (Van Leeuwen 2008; Bosma 2009).

\section{Orientations on the Countries of Origin Emerging Independently from Multicultural Politics}

It is difficult to claim that Dutch multicultural politics have generously sponsored cultural diversity. In the case of the postcolonial immigrants, it is in many respects simply a myth. The establishment of the Moluccan Historical Museum and Indische 
House - both high profile initiatives - were not linked to multiculturalism, but to the Second World War in Asia and the repatriation process itself. In contrast to the Indische and Moluccan institutes in the field of heritage that do receive subsidies, one might say the National Institute for the Study of Dutch Slavery and its Legacy is an outcome of multicultural policies. It was an act of memory politics by the Dutch government, following the example of Great Britain to integrate the legacies of the Atlantic slave trade in public memory. The ethnic festivals, however, that attract so much media attention hardly receive government subsidies. The Indische Pasar Malam receives no government subsidies at all and the (Afro-) Surinamese Kwakoe festival in Amsterdam, which is attended by 400,000 visitors each year, receives a mere pittance. In general, government subsidies for the cultural scenes of the migrants are trivial compared with the size of the immigrant population.

In spite of these hardly conducive national opportunity structures, since the 1990s the percentage of postcolonial migrant organisations involved in preserving their heritage, identity and history has more than doubled (5.5\% versus $2.2 \%$ before 1990$)$ and an even more remarkable growth took place in the number of organisations that were oriented towards the modern country of origin $(12.2 \%$ versus $3.7 \%$ before 1990). If the cultural life of postcolonial migrants has developed more or less without government sponsorship, this is certainly the case for another set of activities that is part of the repertoire of identity seeking, undertaking activities oriented towards the modern country of origin. Migration historians and geographers like Van Amersfoort usually argue that transnationalism is nothing new: if anything has changed it is the density of relationships, made possible by new and cheaply available means of communication and long-distance travel (Van Amersfoort 2001). But for postcolonial migrants transnationalism is something new, or at least is taking new directions. After all, the political relationship between their country of origin and their new land of settlement, the former metropolis, has changed in definition. Most postcolonial migrants were reluctant settlers on Dutch soil. The Indische Netherlanders however could not return to their place of origin. As many as 30,000 of them migrated to the USA, another 10,000 to Australia and smaller groups to a great number of countries all over the world. ${ }^{10}$ Moluccans only began to look towards the Netherlands in the late 1970s when it became clear that the ideal of a free republic of the Moluccas (the Republik Maluku Selatan) would never materialise. Many who had left Suriname because of political instability in 1975 or the unattractive prospect of visa requirements after 1980 dreamt of returning as soon as the situation had calmed down. But in the 1980s, the Surinamese too had to adjust themselves towards the concept of a permanent existence in the Netherlands.

For the overwhelming majority, settlement in the Netherlands proved to be permanent, and this implied a transformation in the relationship with their country of origin. What remained was the solidarity with communities and relatives in back home. In the Moluccan case, the kumpulans, or associations, began to play an increasingly important role in this respect. ${ }^{11}$ These associations, initially meant to maintain contact between the Moluccans dispersed across the Netherlands, over time

\footnotetext{
${ }^{10}$ In addition, it should be noted that from 1949 to 1962 a small proportion of the Indische Netherlanders tried to build a country in New Guinea, until this was annexed in 1962 by Indonesia.

11 The first kumpulan was registered at the Chamber of Commerce in 1952.
} 
began to include villages back in Indonesia. Open contact with relatives and communities in the Moluccas came about in the late 1960s. This led to a better understanding of the situation on Ambon and other Moluccan islands and also to the creation of solidarity organisations (Rinsampessy 1992, 182). From the early 1970s onwards, the Dutch government tried to encourage Moluccans in the Netherlands to visit their relatives overseas, but the first of these 'orientation trips' took place only after the second train hijacking in 1978. Once visits by Moluccans in the Netherlands to the Moluccas had become openly accepted within the Moluccan community in the Netherlands, a growing number of Moluccan organisations geared towards development projects and solidarity projects in the Moluccas emerged: 9 organisations were established in the 1950s, 15 between 1960 and 1990 and 43 since then (IISH 2008).

To help the tens of thousands of Indische Netherlanders who struggled to survive in Indonesia in the economically and politically difficult 1950s, the organisation HALIN (Aid to Compatriots in Need) was founded in 1955 in the Netherlands and has supported thousands of former Dutch citizens who stayed in Indonesia. This organisation still exists today. Once the tensions between Indonesia and its former coloniser eased - the visit of the Dutch queen to Indonesia in 1970 was an important step in that direction - and the cost of air fares decreased over the years, a visit to their country of birth or to the country where they had worked for many years became a real option. Moreover, in the course of time the orientation of the journey became less about the colonial Indische and more oriented towards modern Indonesia. As a concomitant to that, the solidarity of Indische organisations has expanded beyond solidarity with relatives in Indonesia. Tong-Tong, the organiser of the Pasar Malam Besar, the largest Indische festival in the Netherlands, recently held benefit concerts for the Acehnese tsunami victims in 2005 and the victims of the earthquake in Yogyakarta in $2006 .^{12}$

These links with Indonesia are nothing, however, compared with the increasing intensity of the contacts with the West Indies and Suriname in particular. Its independence did not have a negative effect on the intensity of contact between the Surinamese in the Netherland and those in the West Indies. While in 1982, 69,000 persons arrived at Zanderij airport near Paramaribo, their numbers had doubled by 2000. The declining cost of air fares, from the equivalent of about 900 Euros in 1981 to half this amount 20 years later, was most welcome. Particularly interesting is the economic relationship between migrants and their families' homes. In 2006, about $47 \%$ of the families in Suriname received money from relatives in the Netherlands, on average 100 to 500 Euros per year. The total amount involved has increased over the years. In 2006, the total volume of remitted funds was estimated to be in the order of 125 million Euros (Unver and Siegel 2006: 21). Moreover, SurinameseHindustani organisations are both involved in Dutch development co-operation as well as an orientation towards the Indian diaspora. This is in tune with the increasing interest of the Surinamese Hindustani in the Netherlands in metropolitan Indian culture. ${ }^{13}$ Some Hindustani are even making trips to India, although, according to

\footnotetext{
$\overline{12}$ See www.pasarmalambesar.nl festhome.html

13 See www.sevanetwork.net
} 
Nell, these are once in a lifetime visits, in the same way that Afro-Americans visit West Africa (Nell 2008).

The groups who are most actively engaged in linking up with their relatives overseas are the Moluccans and the Surinamese Maroon. This is not surprising because in both cases their places of origin have suffered from war. More than a third of the Maroon organisations in the Netherlands are aimed at the development of their relatives' communities in Suriname. This is a direct consequence of the civil war in the hinterland of Suriname. Likewise, the violent clashes in the Moluccas in 1999 caused great concern among the Moluccans in the Netherlands and led to the establishment of 24 solidarity groups between 1999 and 2001 (IISH 2008). Again, this rise in transnationalism was intertwined with the quest for history and identity and part of the growing desire of postcolonial migrants of the first and second generation to reorient themselves towards their family roots. There has been no relationship between this type of transnationalism and dual citizenship, for the simple reason that practically all postcolonial immigrants only have a Dutch passport. These reorientations took place outside the scope of Dutch multicultural minority policies, of which like in Canada, the facility of dual citizenship has been part.

\section{Conclusions and Discussion}

Comparing the cases of the Indische and the Surinamese organisations, we may have to accede that, apart from a different degree of ethnic and religious heterogeneity, government sponsorship may have caused fragmentation among immigrant organisations. But the big caveat to the point made by Koopmans et al. is that the rise of the number of Surinamese organisations had taken effect much earlier than the emergence of multiculturalism. Government subsidies were more easily available in the early 1970s, a decade before multiculturalism began to inform government policies, and ethnic divisions within the Surinamese population were the product of a pluralistic colonial society. Surinamese and Indische immigrants differed in social capital but also found different opportunity structures, and these reinforced the other and played out in a remarkable difference of scale of their organisations. While multiculturalism has definitely impacted upon the organisational life of postcolonial migrants, Dutch government policies, as far as they can be considered to be multicultural, have had a very limited impact, precisely because these policies involved cutbacks in the subsidies given to migrant organisations in the 1980s. The theory of organisational ecology submits that the number of newly founded organisations develop in a curve. This theory however imparts an important role to opportunity structures and assumes that they provide the necessary but limited resources for organisations. The second curve of Indische/repatriated and Moluccan organisations contradicts the assumption of limited resources and should be explained in terms of a specific historical trajectory.

In sum, our data concerning the Dutch postcolonial immigrants do not support the position that politics of multiculturalism have excessively sponsored migrant organisations causing their fragmentation and having adverse consequences for these organisations' effectiveness and thus for the processes of political incorporation of 
immigrants at large. This conclusion may underline the importance of other research into the conditions under which government assistance to immigrant organisations can positively impact processes of social and political incorporation of newcomers. In contrast to our case study, such research should be based upon different categories of immigrants and different countries. In this respect, reference can be made to Bloemraad's work on North America (Bloemraad 2006a, b) for example.

Open Access This article is distributed under the terms of the Creative Commons Attribution Noncommercial License which permits any noncommercial use, distribution, and reproduction in any medium, provided the original author(s) and source are credited.

\section{References}

Alba, R. D., \& Nee, V. (2003). Remaking the American mainstream: assimilation and contemporary migration. Cambridge: Harvard University Press.

Beets, G et al. (2002) De demografische geschiedenis van de Indische Nederlanders. Report no. 64, 89 $(111,113)$. The Hague: NiDi

Bloemraad, I. (2006a). Becoming a citizen in the United States and Canada: structured mobilization and immigrant political incorporation. Social Forces, 85(2), 667-695.

Bloemraad, I. (2006b). Becoming a citizen: incorporating immigrants and refugees in the United States and Canada. Berkeley: University of California Press. etc.

Böcker, A., \& Thränhardt, D. (2003). Is het Duitse integratiebeleid succesvoller, en zo ja, waarom. Migrantenstudies, 19(1), 33-44.

Bosma, U. (2009). Terug uit de koloniën. Bert Bakker: Zestig jaar postkoloniale migranten en hun organisaties. Amsterdam.

Calhoun, G (ed.) (1994) Social theory and the politics of identity. Oxford: Blackwell

Campfens, H. (1979). The integration of ethno-cultural minorities: a pluralist approach. The Netherlands and Canada: a comparative analysis of policy and programme. The Hague: Ministry of CRM/ Staatsuitgeverij.

Engelen, E. (2008). Review symposium: contested citizenship: immigration and cultural diversity in Europe by Ruud Koopmans, Paul Statham, Marco Guigni and Florence Passy: through a looking glass, darkly. Ethnicities, 8(1), 128-133.

Fennema, M. (2004). The concept and measurement of ethnic community. Journal of Ethnic and Migration Studies, 30(3), 429-447.

Gunew, S. (1997). Postcolonialism and multiculturalism: between race and ethnicity. The Yearbook of English Studies, 27, 22-39.

Hannan, M. T., \& Freeman, J. (1989). Organizational ecology. Cambridge: Harvard University Press.

International Institute of Social History (IISH) (2008) Database postcolonial migrant organisations, version 13 June 08.

Jones, G. (2007). Tussen Onderdanen, Rijksgenoten en Nederlanders. Nederlandse politici over burgers uit Oost en West en Nederland 1945-2005. Amsterdam: Rozenberg.

Kastoryano, R. (2008). Contested citizenship. Ethnicities, 8(1), 133-139.

Koopmans, R. (2002). Zachte heelmeesters'.... Een vergelijking van de resultaten van het Nederlandse en Duitse integratiebeleid en wat de WRR daaruit niet concludeert. Migrantenstudies, 18(2), 87-92.

Koopmans, R., Statham, P., Giugni, M., \& Passy, F. (2005). Contested citizenship. Immigration and cultural diversity in Europe. Minneapolis: University of Minnesota Press.

Kraak, J. H., et al. (1958). De repatriëring uit Indonesië. Een onderzoek naar de integratie van de gerepatrieerden uit Indonesië in de Nederlandse samenleving. Amsterdam: Instituut voor Sociaal Onderzoek van het Nederlandse Volk.

Minkoff, D. (1995). Organizing for equality. The evolution of women's and racial-ethnic organisations in America (pp. 1955-1985). New Brunswick: Rutgers University Press.

Nell, L., (2008) Transnational migrant politics in the Netherlands. Historical structures and current events. Ph.D. thesis, Amsterdam, December 
Penninx, R., \& Schrover, M. (2001). Bastion of bindmiddel? Organisaties van migranten in historisch perspectief. Amsterdam: Instituut voor Migratie en Etnische Studies.

Penninx, R., \& Slijper, B. (1999). Voor elkaar? Integratie, vrijwilligerswerk en organisaties van migranten. Amsterdam: IMES.

Penninx, R., \& van Heelsum., A. (2004). Bondgenoot of spelbreker? Organisaties van immigranten en hun mogelijke rol in integratieprocessen. Utrecht: Forum

Prins, B. (2002). The nerve to break taboos: new realism in the Dutch discourse on multiculturalism. Journal of International Migration and Integration (JIMI), 3(3 and 4), 363-379.

Rinsampessy, E. (1992). Saudara Bersaudara. Molukse identiteit in processen van cultuurverandering. Assen: Van Gorcum.

Scheffer, P. (2000) 'Het multiculturele drama', NRC Handelsblad, 29 January

Smeets, H., \& Steijlen, F. (2006). In Nederland gebleven. De geschiedenis van Molukkers 1951-2006. Amsterdam: Bert Bakker.

Sociaal Cultureel Planbureau (SCP). (2007). Jaarrapport Integratie 2007. The Hague: Sociaal Cultureel Planbureau.

Tillie, J., \& Fennema, M. (1997). Turkse organisaties in Amsterdam: een netwerkanalyse. Amsterdam: Het Spinhuis.

Tjenkeh (1982). Onafhankelijk Moluks Maandblad (1978-1986).

Unver, Brigitte and Melissa Siegel (2006) The Netherlands-Suriname Corridor for Worker's Remittances. Study prepared for the World Bank and the Dutch Ministry of Finance. Utrecht, 2006

Van Amersfoort, H. (2001). Transnationalisme, moderne diaspora's en sociale cohesie. Amsterdam: Instituut voor Migratie en Etnische Studies (NWO Essay).

Van Amersfoort, H., \& van Niekerk, M. (2006). Immigration as a colonial inheritance: post-colonial immigrants in the Netherlands, 1945-2002. Journal of Ethnic and Migration Studies, 32(3), 323-346.

Ministerie van Binnenlandse Zaken (1981) Ontwerp-minderhedennota. 's-Gravenhage: Ministerie van Binnenlandse Zaken.

Van Doorn, J. A. A., \& Schuyt, C. J. M. (1978). De stagnerende verzorgingsstaat. Meppel: Boom.

Van Heelsum, A. (2001). Marokkaanse organisaties in Nederland. Een netwerkanalyse. Amsterdam: Het Spinhuis.

Van Heelsum, Anja (2004) Migrantenorganisaties in Nederland, vol. 2. Utrecht: Forum

Van Leeuwen, L. (2008). Ons Indisch Erfgoed. Zestig jaar strijd om cultuur en identiteit. Amsterdam: Bert Bakker.

Van Niekerk, M. (2002). Premigration legacies and immigrant social mobility: the Afro-Surinamese and Indo-Surinamese in the Netherlands. Lanham: Lexington Books.

Vermeulen, Floris (2006) The immigrant organizing process. Turkish organizations in Amsterdam and Berlin and Surinamese organizations in Amsterdam 1960-2000. IMISCOE Dissertations. Amsterdam: AUP.

Wetenschappelijke Raad voor het Regeringsbeleid (1989) Allochtonenbeleid. 's-Gravenhage: Staatsuitgeverij.

Wetenschappelijke Raad voor het Regeringsbeleid (WRR) (1979), Etnische Minderheden, 17, 1979. The Hague: Staatsuitgeverij

Willems, W. (2001). De uittocht uit Indië, 1945-1995. Amsterdam: Bert Bakker.

Ulbe Bosma is Senior Researcher at the International Institute of Social History. He published on colonial and postcolonial history. Among his most recent publications are (with Remco Raben) Being 'Dutch' in the Indies. A History of Creolisation and Empire 1500-1920 (2007), Terug uit de Koloniën. Zestig jaar postkoloniale migranten en hun organisaties (2009) (Back from the Colonies. Sixty years postcolonial migrants and their organisations).

Marga Alferink has studied Social Anthropology at Leiden University. As an assistant researcher at the International Institute of Social History, she compiled the database of postcolonial migrant organisations on which this article is based. In addition, she wrote an article on the impact of multicultural policies on postcolonial festivals in the Netherlands (under review). Currently, she is preparing a study on the process of integration on an allotment garden in Leiden. 